\title{
MADE BY CHILDREN: THE EXPLOITATION OF CHILD LABOUR IN AGRICULTURE, INDUSTRY AND THE SERVICE SECTOR IN MAINLAND CHINA
}

\author{
Cindy Nguyen ${ }^{1}$ \\ ${ }^{1}$ Law Student of Law School, University of Wollongong, Australia \\ E-mail : cindy_dh_ngunyen@gmail.com
}

Submitted: 2017-08-28 | Accept: 2017-09-25

\begin{abstract}
This research essay examines the exploitation of child labour in agriculture, industry and the service sector in Mainland China. Child productivity in China has historically been essential to the survival of the family. However, the globalized environment has drawn emphasis to the reality that children are exploited and subject to dangerous work conditions. The aim of this research is to analyse the international legal framework and human rights conventions safeguarding the rights of the child. This involved the primary analysis of the Convention on the Rights of the Child, the Minimum Age Convention, the Universal Declaration of Human Rights and the Worst Forms of Child Labour Convention. The Procedure of the Conclusion of Treaties, Minors Protection Law, Provisions on the Prohibition of Using Child Labour, Regulations Banning Child Labour and Compulsory Education Law were critiqued to determine the effectiveness of China's domestic legislation. The results demonstrated that child labour is currently not prohibited under China's domestic law, a consequence of ineffective implementation of international treaties. To support this legal analysis, it evaluated academic research exploring the economic and cultural circumstances of China. It was found that globalization, rapid economic growth, a lack of education and social and cultural constructions of 'child' and 'childhood' further contributed to the existence of child labour. The significance of these findings is that it highlights the difficulty involved in changing legislation when the economic and cultural forces strongly dictate against it. Children are ultimately unable to access justice as effectively as their adult counterparts do within China's legal framework
\end{abstract}

Keywords: child labour, children's rights, international treaties, China, globalisation, filial piety

\section{INTRODUCTION}

Child labour is a contemporary and significant human rights issue. It is work performed by a child that is 'likely to... interfere with [his or her] education, or to be harmful to [his or her] health or physical, mental, spiritual, moral or social development'. Although historically in Asia, and more specifically in Mainland China a child's productivity was essential to the family's survival, an increasingly globalised legal practice and trading environment has highlighted the reality that children are exploited and subject to

\footnotetext{
${ }^{1}$ Convention on the Rights of the Child, opened for signature 20 November 1989, 1577 UNTS 3 (entered into force 2 September 1990) art 32.1.
} 
dangerous work conditions. The purpose of this research essay will therefore be to examine the international framework and human rights conventions and its effectiveness in safeguarding the rights of the child. By way of contrast, it will critique the legal, economic, social and cultural circumstances of China that continue to contribute to the exploitation of children, particularly in the agriculture, industry and service sector. This includes an exploration of China's ratification of international treaties and conventions and their ineffective domestic implementation, globalisation, ${ }^{2}$ rapid economic growth, ${ }^{3}$ limited education ${ }^{4}$ and social and cultural constructions of 'child' and 'childhood'. 5 It will analyse the costs of exploiting child labour through the lens of the child, the economy, the employer and the wider society. In doing so, this research aims to provide insight into how the Chinese legal system operates within an international setting. It will demonstrate how legal practice is consequently impacted, and how children are unable to access justice effectively as their adult counterparts within China's current legal framework. The

\footnotetext{
2 Erica G Polakoff, 'Globalisation and Child Labour' (2007) 23 Journal of Developing Societies 259, 260.

3 Sunwook Chung, 'Explaining Compliance: A Multi-Actor Framework for Understanding Labour Law Compliance in China' (2014) 68 Human Relations 237, 237.

${ }^{4}$ Minli Liao and Jun Sung Hong, 'Child Labour in the People's Republic of China: An Ecological Systems Analysis' (2010) 54 International Social Work 565, 572.

${ }^{5}$ Polakoff, above n 2, 263.

research questions guiding this analysis include: (1) How does the international treaties and human rights conventions impact on child labour rights in Mainland China? (2) What are the effects of Mainland China's domestic law on child labour rights? (3) What are the effects of globalization, economic growth, limited education and social and cultural constructions of 'child' and 'childhood' on the existence of child labour?

\section{LEGAL MATERIALS AND METHODS}

The data obtained for this research paper is based on a primary analysis of the relevant provisions of the Convention on the Rights of the Child, ${ }^{6}$ the Minimum Age Convention, ${ }^{7}$ the Universal Declaration of Human Rights ${ }^{8}$ and the Worst Forms of Child Labour Convention. ${ }^{9}$ The research also examined China's domestic law including the Procedure of the Conclusion of Treaties, ${ }^{10}$ Minors Protection Law, ${ }^{11}$

\footnotetext{
${ }^{6}$ Convention on the Rights of the Child, opened for signature 20 November 1989, 1577 UNTS 3 (entered into force 2 September 1990).

${ }^{7}$ Minimum Age Convention, opened for signature 26 June 1973, C No 138 (entered into force 19 June 1976) ('ILO Convention No 138').

${ }^{8}$ Universal Declaration of Human Rights, GA Res 217A (III), UN GAOR, $3^{\text {rd }}$ sess, $183^{\text {rd }}$ plen $\mathrm{mtg}$, UN Doc A/810 (10 December 1948).

${ }^{9}$ Worst Forms of Child Labour Convention, opened for signature 17 June 1999, C No 182 (entered into force 19 November 2000) ('ILO Convention No 182').

10 Procedure of the Conclusion of Treaties (The People's Republic of China) National People's Congress, Order No 37, 28 December 1990 ('The Treaty Procedure Law').
} 
Provisions on the Prohibition of Using Child Labour, ${ }^{12}$ Regulations Banning Child Labour $^{13}$ and Compulsory Education Law. ${ }^{14}$ The rationale behind this research approach was to identify and examine both the international and domestic legal framework safeguarding the rights of the child. Therefore, to support the interpretation of the relevant provisions, research into case law to demonstrate the law in action was conducted. This proved unsuccessful however. There were difficulties in accessing reported case law from Chinese legal databases. Alternatively if cases were reported, there was the additional challenge in translating the case into the English language. As the research was unable to provide commentary on the practical effects of the law in individual cases, it suffered limitations in this aspect. As a result, secondary data obtained through various academic research was used to draw out the practical implications of the law.

Given the primary analysis focused on the interpretation of the legislation, this meant that the policy considerations underlying the legislation were often

\footnotetext{
${ }^{11}$ Minors Protection Law (The People's Republic of China) National People's Congress, 1 June 2007.

12 Provisions on the Prohibition of Using Child Labour (The People's Republic of China) National People's Congress, Decree No. 364, 1 October 2002.

${ }^{13}$ Regulations Banning Child Labour (The People's Republic of China) National People's Congress, 2002.

14 Compulsory Education Law (The People's Republic of China) National People's Congress, Order No 38, 12 April 1986.
}

marginalized in the discussion. To overcome this limitation and support the legal analysis, data was obtained from various academic research exploring China's economic and cultural circumstances. Although there was a sheer volume on studies exploring China's cultural circumstances, a limitation was that there lacked an economic study of child labour in China, and hence official statistics of the number of child labourers. This meant that the discussion concerning globalization and rapid economic growth in this research was quite general and lacked specific application to China. A consequence of this limitation was that the vast majority of the secondary research sourced employed qualitative research methods. This research therefore lacked any substantive quantitative data to support the findings.

\section{RESULT AND DISCUSSION}

\section{International Framework on Child}

\section{Labour and Human Rights Conventions}

Child labour is prohibited by international law and any contracting State that does not meet this international responsibility violates several international treaties and human rights conventions. The international standards which safeguard the rights of the child consist of the Universal Declaration of Human Rights, ${ }^{15}$ the $U N$ Convention on the Rights of the Child

\footnotetext{
${ }^{15}$ Universal Declaration of Human Rights, GA Res 217A (III), UN GAOR, $3^{\text {rd }}$ sess, $183^{\text {rd }}$ plen $\mathrm{mtg}$, UN Doc A/810 (10 December 1948).
} 
$1989,{ }^{16}$ the ILO Convention No 138 on the

Minimum Age for Admission to Employment and Work ('ILO Convention No 138') ${ }^{17}$ and the ILO Convention No 182 on the Worst Forms of Child Labour 1999 ('ILO Convention No 182'). ${ }^{18}$

The Universal Declaration of Human Rights $^{19}$ states the fundamental rights and freedoms to which all human beings are entitled. A child in particular is "entitled to special care and assistance', ${ }^{20}$ and has the 'right to education, ${ }^{21}$ and the right to be free from exploitation ${ }^{22}$ and slavery. ${ }^{23}$ Although this declaration is not legally binding, it has been employed by States to set standards and guide the development of otherwise legally binding conventions safeguarding the rights of children. ${ }^{24}$ The implication of this is that the extent of human rights and more specifically, the rights of the child continue to be challenged given the difficulties involved in enforcing a

${ }^{16}$ Convention on the Rights of the Child, opened for signature 20 November 1989, 1577 UNTS 3 (entered into force 2 September 1990).

${ }^{17}$ Minimum Age Convention, opened for signature 26 June 1973, C No 138 (entered into force 19 June 1976) ('ILO Convention No 138').

${ }^{18}$ Worst Forms of Child Labour Convention, opened for signature 17 June 1999, C No 182 (entered into force 19 November 2000) ('ILO Convention No 182').

${ }^{19}$ Universal Declaration of Human Rights, GA Res 217A (III), UN GAOR, $3^{\text {rd }}$ sess, $183^{\text {rd }}$ plen $\mathrm{mtg}$, UN Doc A/810 (10 December 1948).

${ }^{20}$ Ibid art 25.2.

${ }^{21}$ Ibid art 26.

22 Ibid art 23.

${ }^{23}$ Ibid art 4.

24 Bonny Ibhawoh, 'Human Rights for Some: Universal Human Rights, Sexual Minorities and the Exclusionary Impulse' (2014) 69 International Journal 612, 613. declaration that lacks legal authority. Without a legally binding international declaration, 'universal human rights remain [in principal] aspirational', ${ }^{25}$ as its influence internationally is dependent on its moral claims.

The UN Convention on the Rights of the Child $1989^{26}$ in contrast is legally binding for ratifying States. It recognises that human beings below the age of eighteen years are considered children, ${ }^{27}$ and that as a vulnerable group in society, they should be afforded protection. ${ }^{28}$ States contractually bound by this Convention agree to take 'all appropriate legislative, administrative, social and educational measures to protect the child from all forms of physical or mental violence, injury or abuse, neglect or negligent treatment, maltreatment or [economic] exploitation'. ${ }^{29}$ By having the Committee on the Rights of the Child examine the progress made by States in meeting their international obligations, ${ }^{30}$ significant pressure is exerted on contracting States to implement the Convention into domestic law.

\footnotetext{
${ }^{25}$ Ibid 614.

${ }^{26}$ Convention on the Rights of the Child, opened for signature 20 November 1989, 1577 UNTS 3 (entered into force 2 September 1990).

${ }^{27}$ Ibid art 1.

28 Jean Grugel, 'Children's Rights and Children's Welfare After the Convention on the Rights of the Child' (2012) 13 Progress in Development Studies $19,21$.

${ }^{29}$ Convention on the Rights of the Child, opened for signature 20 November 1989, 1577 UNTS 3 (entered into force 2 September 1990) art 19.

30 Nigel Thomas, 'Children's Rights: Policy into Practice' (2011) 4 Centre for Children and Young People: Background Briefing Series 1, 12.
} 
The International Labour Organisation ('ILO') is a UN agency that sets and maintains labour and social standards through its legally binding conventions. ${ }^{31}$ ILO Convention No 138 specifies the legal minimum age for admission to any type of employment or work as 'not less than fifteen years'. ${ }^{32}$ ILO Convention No 182 requires '[States] to take immediate action to prohibit and eliminate the worst forms of child labour ${ }^{33}$ in pursuit of the long-term goal of the effective elimination of all child labour. Where contracting States fail to implement their international obligations domestically, the International Labour Conference ('ILC') may decide on the sanction. ${ }^{34}$

Despite the supervisory mechanisms in place to encourage contracting States to meet their international obligations, international treaties, even after ratification, accession or approval, do not automatically become part of national law and accordingly do not automatically have domestic legal effect. ${ }^{35}$ Although symbolically contracting States assume international responsibility, it is in practical reality the actions of each

31 Nick Axford, 'Exploring the Influence of International Governmental Organisations on Domestic Child Welfare Policy and Practice' (2013) 37 Adoption \& Fostering 57, 59.

${ }^{32}$ ILO Convention No 138 art 2.

${ }^{33}$ Axford, above $\mathrm{n} 22$.

34 Sara Kahn-Nisser, 'External Governance, Convention Ratification and Monitoring: The EU, the ILO and Labour Standards in EU Accession Countries' (2014) 20 European Journal of Industrial Relations 383, 388.

${ }^{35}$ Hanqin Xue and Qian Jin, 'International Treaties in the Chinese Domestic Legal System' (2009) 8 Chinese Journal of International Law 299, 300.
State at the domestic level, in the form of enacted laws, policies and regulations that are indispensable in fulfilling their international obligations. Furthermore, provided they enter reservations and that these reservations do not prevent them from complying with the Convention more generally, contracting States do not have to comply with particular articles in treaties because of domestic circumstances that prevent them in doing so. ${ }^{36}$ The effectiveness of international law is consequently limited by the need to have States specifically incorporate international obligations through their domestic legislation. This calls into question the effectiveness of the international legal framework in meaningfully and practically safeguarding the rights of the child.

\section{Causes of Child Labour}

It is estimated that 150 million children between the ages of five to fourteen worldwide are engaged in child labour. ${ }^{37}$ In regards to the number of children engaged in child labour in China, there are no official statistics nor are there cases of child labour that have been reported to the ILO. ${ }^{38}$ Despite a lack of statistical data and case law, what is known is that the existence of

\footnotetext{
${ }^{36}$ Thomas, above n 21,8 .

${ }^{37}$ UNICEF Global Databases, Child Labour: Current Status and Progress (2016) $<$ https://data.unicef.org/topic/childprotection/child-labour/\#>.

${ }^{38}$ International Labour Organisation, Child Labour in China and Mongolia <http://ilo.org/beijing/areasof-work/child-labour/lang--en/index.htm>.
} 
child labour in the agriculture, industry and service sector is context-specific, ${ }^{39}$ and requires a consideration of China's legal, economic, social and cultural circumstances. What this suggests is that there are many types of child labour, and there are different characteristics depending on whether the child is employed in the agriculture, industry or service sector. For the purposes of this research, 'agriculture' includes 'farming, fishing, aquaculture, forestry and livestock'. ${ }^{40}$ The 'industry' sector includes 'mining and quarrying, manufacturing, construction and public utilities'. ${ }^{41}$ The 'service' sector consists of 'wholesale and retail trade; restaurants and hotels; transport, storage and communications; finance, insurance, real estate and business services; and community as well as social personal services'. 42

One of the most distinguishing characteristics of agricultural work is that it is carried out in a rural environment. The 'family farm element in agriculture that is so bound up with culture and tradition makes it difficult to acknowledge that children can be exploited in such a setting, ${ }^{43}$ However, the

\footnotetext{
${ }^{39}$ Liao and Hong, above n 4, 567.

${ }^{40}$ International Labour Organisation, Child Labour in Agriculture

$<$ http://ilo.org/ipec/areas/Agriculture/lang-en/index.htm>.

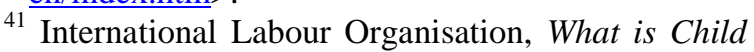
Labour <http://ilo.org/ipec/facts/lang-en/index.htm>.

42 Ibid.

43 Peter Hurst, 'Health and Child Labour in Agriculture' (2007) 28 Food and Nutrition Bulletin $364,366$.

reality is that working in a rural environment poses major hazards to children, including long hours during planting and harvesting, physically demanding and strenuous work, the exposure to extreme temperatures, the exposure to dangerous tools and machinery as well as exposure to toxic pesticides. ${ }^{44}$ These hazards can threaten a child's physical, mental and emotional well-being. If these hazards exist coupled with the fact that a child is prevented from attending school, this will constitute as child labour. ${ }^{45}$

A characteristic of child labour in the industry sector is that work is carried out under the employment of a large or global corporation. Like the agricultural sector, children working in the industry sector face long hours when mining or manufacturing, unsafe work conditions as well as exposure to hazardous tools and machinery. However, the percentage of child labourers in this area is significantly smaller than the percentage of child labourers involved in agriculture. ${ }^{46}$ This could be explained by the fact that being a global corporation, this inevitably draws the watchful eye of the international community. There is greater international pressure placed on corporations to adhere to the international treaties and human rights conventions which safeguard the rights of the child. By not complying with these

\footnotetext{
${ }^{44}$ Ibid.

${ }^{45}$ Convention on the Rights of the Child, opened for signature 20 November 1989, 1577 UNTS 3 (entered into force 2 September 1990) art 32.1.

${ }^{46}$ International Labour Organisation, above n 40.
} 
standards, corporations risk being condemned globally and risk the failure of their operations.

In the services sector, child labour is characterised by tasks undertaken at a more local level. This may mean however, that cases of child labour go unreported because of a lack of cultural condemnation against the practice. Coupled with this, is the lack of international awareness of such practices employed by local businesses or families. The implication of this is that it is difficult to completely eliminate child labour in the service sector, particularly when a child's productivity is culturally valued. ${ }^{47}$

\section{i. China's Ratification of International Treaties and Conventions and its Domestic Implementation}

A fundamental tenet of Chinese law and its policies of foreign affairs has been the implementation of its international obligations. ${ }^{48}$ As a result, China has ratified major international documents with regard to protecting children's rights, including the Convention on the Rights of the Child $1989,{ }^{49}$ the ILO Convention No 138 and the ILO Convention No 182.

Currently, the Chinese Constitution is silent on the legal status of international treaties and their hierarchy in their domestic

\footnotetext{
${ }^{47}$ Polakoff, above n 2, 263.

${ }^{48}$ Xue and Jin, above $\mathrm{n} 26$.

${ }^{49}$ Convention on the Rights of the Child, opened for signature 20 November 1989, 1577 UNTS 3 (entered into force 2 September 1990).
}

legal system. ${ }^{50} \mathrm{~A}$ consequence of this is that there exist differing views concerning the legal effects of international treaties. However, the Constitution does stipulate that the 'State Council has the power to conclude treaties and agreements with foreign states, ${ }^{51}$ the Standing Committee of the National People's Congress ('NPC') $)^{52}$ decides on the ratification of treaties, ${ }^{53}$ while the President of the PRC ratifies treaties and agreements with foreign states' ${ }^{54}$ These same provisions are echoed in the Procedure of the Conclusion of Treaties ('The Treaty Procedure Law') ${ }^{55}$ whereby the status of international treaties must be in accordance with this law and fulfil necessary domestic legal procedures'. ${ }^{56}$ The implication of this is that 'subject to domestic legal procedures, international treaties in which [China is a contracting State] have binding force in domestic law'. 57 This does not however include any reservations China has made.

The enforcement of treaty obligations and their domestic implementation therefore

\footnotetext{
50 Wuhong Shi, 'The Application of Treaties in China: Practice, Problems and Prospects' (2012) 1 Journal of International Law 114, 115.

${ }^{51}$ [Constitution of the People's Republic of China] art 89.

52 [Constitution of the People's Republic of China] art 57.

53 [Constitution of the People's Republic of China] art 67(14).

${ }^{54}$ [Constitution of the People's Republic of China] art 81

55 Procedure of the Conclusion of Treaties (The People's Republic of China) National People's Congress, Order No 37, 28 December 1990 ('The Treaty Procedure Law').

${ }^{56}$ Xue and Jin, above n 26.

${ }^{57}$ Ibid.
} 
remains a significant challenge particularly because of the uncertainty that surrounds the status of international treaties in Chinese law. Although China assumes international responsibility for upholding the treaty obligations, the realisation of such obligations is dependent on what their domestic legal procedures are, ${ }^{58}$ which involves 'ratification by the Standing Committee of the NPC, approval by the State Council, submission to the State Council for the record and submission to the Foreign Ministry for registration'. ${ }^{59}$ There is much discretion within these procedures, ${ }^{60}$ bringing into question the effectiveness of China's domestic implementation of international obligations given the State Council may disprove the treaty obligations.

Along with China's ratification of international treaties, China also has domestic legislation that protects the rights of the child. The primary law is the Minors Protection Law, ${ }^{61}$ which states that children have the 'right to life, the right to development, the right to being protected and the right to participation... [where the State must] ensure the inviolability of [a child's] lawful rights and interests'.62 However, this legislation does not outlaw the employment of child labourers in service

\footnotetext{
${ }^{58}$ Xue and Jin, above $\mathrm{n} 26$.

${ }^{59}$ Shi, above n 36, 125.

${ }^{60}$ Ibid.

${ }^{61}$ Minors Protection Law (The People's Republic of China) National People's Congress, 1 June 2007.

${ }^{62}$ Ibid art 3.

sectors, nor does it enforce the cap on working hours for children. The effectiveness of China's domestic legislation is called into question, as there remain enforcement difficulties, which allow child labour to persist in China.

\section{ii. Globalisation}

Globalisation has inherently increased and perpetuated the cycle of poverty in China, which has consequently made children more vulnerable to exploitation. Globalisation is not a new concept ${ }^{63}$ and involves removing barriers to free trade and the closer integration of national economies. ${ }^{64}$ What is facilitated by this removal is foreign investment, allowing 'foreign ownership and exploitation of national resources, [gearing] local economies toward export production... and [removing] the barriers to the influx of foreign goods onto the local market'. ${ }^{65}$ Foreign investment is a significant indicator of economic development, which involves improving 'economic opportunities, quality of human lives and reduction in poverty'. ${ }^{66}$ However instead of reducing poverty, what globalisation has ultimately created and perpetuated is poverty worldwide, with China being no exception to this effect.

\footnotetext{
${ }^{63}$ Muhammad Akram Ch et al, 'Globalisation and its Impact on the World Economic Development' (2011) 2 International Journal of Business and Social Science 291, 292.

${ }^{64}$ Polakoff, above n 2, 262.

${ }^{65}$ Ibid 277.

${ }^{66}$ Ch, above n 49, 291.
} 
A consequence of poverty has been the inherent exploitation of workers in China, particularly children between the ages of five and fourteen years. These children have been forced to labour on farms, in factories and as street vendors, whose economic contribution is essential to the survival of their families. ${ }^{67}$ This is because the development of free trade agreements have equipped global corporations with the power to bypass and violate environmental protections, workplace health and safety regulations and child labour laws. ${ }^{68}$ The effects of globalization do however vary depending on whether the child is employed in the agriculture, industry or service sector. A child who is employed by a global corporation in the industry sector may draw greater international condemnation as opposed to a child working in a small family operation in the services sector. As there may be foreign investors of the corporation, there is a greater likelihood that the corporation's practices will gain the attention of the international community and potentially become investigated if claims are made as to the employment of child labour. Regardless of the sector, increased poverty caused by an increasingly globalised trading environment has made children and their labour more vulnerable to being exploited.

\footnotetext{
${ }^{67}$ Polakoff, above n 2, 262.

${ }^{68}$ Ibid 278.
}

\section{iii. Rapid Economic Growth}

China's rapid economic growth requires a greater supply of labour, with the exploitation of child labour as a method of meeting this demand. This rapid economic growth is attributed to the Open Reform policy that began in 1978, where China shifted from a centrally planned economy to a socialist market economy. ${ }^{69}$ Through the provision of favourable investment and preferential policies, there was economic prosperity in certain regions. ${ }^{70}$

A side effect of China's rapid economic growth however has been pressure placed on the Chinese economy to meet the demand of not only supplying labour, but supplying cheap labour. This result can be attributed to globalisation, where essential to reaping the highest profit requires global capital to seek out the cheapest labour force. Child labour therefore maximises the profit of major global corporations and allows them to achieve cost competitiveness. ${ }^{71}$ This is particularly the case with global corporations employing child labourers in China's industry sector to mine minerals which are used in the production of major electronics. By moving their production operations to China, corporations exploit children to source cheap labour as a human

\footnotetext{
${ }^{69}$ Liao and Hong, above n 4, 569.

${ }^{70}$ Ibid.

71 Michael Dunford et al, 'Globalisation, Cost Competitiveness and International Trade: The Evolution of the Italian Textile and Clothing Industries and the Growth of Trade with China' (2016) 23 European Urban and Regional Studies 111,115 .
} 
resource strategy to reduce employee cost. Often these children's wages are extremely low and long hours are worked without overtime pay or health benefits. $^{72}$ Furthermore, not only does child labour significantly lower employee cost, it creates a more 'manageable"73 labour force. Children are more likely to be unaware of the full extent of their rights and are therefore 'less likely to object to conditions of work or employment practices' ${ }^{74}$ Although these aspects of economic growth prove attractive to global corporations and employers, it otherwise reduces children to mere assets in generating profit for companies, and nothing more meaningful or valuable. Further, the degree to which the child labourer contributes to economic growth is dependent on whether the child is employed in agriculture, industry or the service sector, with the industry sector closely tied to foreign investment and hence economic development. The greater and more global the scale of operation, the greater potential it has to benefit the economy. Economic growth in China is ultimately premised on the exploitation of child's rights.

\section{iv. Limited Education}

Child labour participation in China is positively correlated with low levels of

\footnotetext{
${ }^{72}$ Polakoff, above n 2, 270.

73 Ibid 271.

${ }^{74}$ Ibid 270.

education. Although the economic reform stimulated greater investment in education in order to produce highly skilled workers, China's decentralised fiscal system resulted in rural schools in Inland and Western regions receiving minimal financial support from the central government. ${ }^{75}$ This is in contrast to urban schools in the Eastern region, which received greater financial support. A 'lack of educational resources, underqualified teachers and substandard school facilities gradually led to increasing numbers of children leaving school, where they had little or no access to adequate educational resources' ${ }^{76}$ A consequence of this is that children have few options other than to work to survive.

Against the background of an increasingly globalised educational practice, China has 'been exploring a development path with unique Chinese characteristics... and [seeking] convergence and coupling mechanism of a combination of both Chinese and Western styles [of education]' ${ }^{77}$ Although the landscape of China's educational development has improved to overcome the disparity in education between rural and urban areas through Compulsory Education Law, ${ }^{78}$

\footnotetext{
${ }^{75}$ Liao and Hong, above n 4.

${ }^{76}$ Ibid.

77 Zhongjing Huang, Ting Wang and Xiaojun Li, 'The Political Dynamics of Educational Changes in China' (2016) 14 Policy Futures in Education 24, 25.

78 Compulsory Education Law (The People's Republic of China) National People's Congress, Order No 38, 12 April 1986.
} 
whereby children must have nine years of compulsory education, the transition has been challenged by the tension between tradition and modernisation. Chinese education has been modernised through the ideals of 'discovery and innovative ideas' ${ }^{79}$ However, ideology and more specifically traditional Chinese values of 'jing', that is, obedience and family allegiance are inevitably embedded in and enacted in schooling through explicit and implicit curricula. ${ }^{80}$ The implication of this is that despite educational improvements for children both in rural and urban regions, children may be propelled to leave school to contribute economically to their family's survival as a result of cultural values.

\section{v. Social and Cultural Constructions of 'Child' and 'Childhood'}

'An individual may be considered a child in one culture, but an adult in another, with radically different responsibilities and expectations'. ${ }^{81}$ This is the case in China, where the meaning of 'child' and 'childhood' are embedded in the socioeconomic and cultural contexts of traditional China, ${ }^{82}$ which allow child labour to exist. Historically, families in China relied on agricultural labour productivity that involved all household members. Such

\footnotetext{
${ }^{79}$ Huang, Wang and Li, above $\mathrm{n} 63$.

${ }^{80}$ Fengshu Liu, 'Negotiating the Filial Self' (2008)

16 Nordic Journal of Youth Research 409, 418.

${ }^{81}$ Polakoff, above n 2, 263.

${ }^{82}$ Ibid.
}

work was not deemed exploitative, but rather, essential for the family's survival. ${ }^{83}$ Although a child in China is considered as someone under the age of eighteen ${ }^{84}$ and the minimum legal working age is sixteen years old, ${ }^{85}$ Confucian family values, which inform the relationships within the familial system, strongly override ${ }^{86}$ and consequently define a child's role and responsibility in society. These circumstances provided the conditions for the development of filial piety, ${ }^{87}$ which prescribes the relations and obligations between parents and children. ${ }^{88}$

Filial piety perpetuates child labour in China given the importance of Confucian values in traditional Chinese families. It has two distinct meanings, reciprocal filial piety and authoritarian filial piety. ${ }^{89}$ Reciprocal filial piety or 'xiao' requires children to reciprocate by caring for parents in later life; it 'entails gratitude and willingness to repay

\footnotetext{
${ }^{83}$ Liao and Hong, above n 4, 568.

${ }^{84}$ Minors Protection Law (The People's Republic of China) National People's Congress, 1 June 2007, art 2.

85 Provisions on the Prohibition of Using Child Labour (The People's Republic of China) National People's Congress, Decree No. 364, 1 October 2002, art 6.

86 Yang $\mathrm{Hu}$ and Jacqueline Scott, 'Family and Gender Values in China: Generational, Geographic and Gender Differences' (2014) 37 Journal of Family Issues 1267, 1269.

87 Xuewen Sheng and Barbara H. Settles, 'Intergenerational Relationships and Elderly Care in China' (2006) 54 Current Sociology 293, 299.

88 Kuang-Hui Yeh et al, 'Filial Piety in Contemporary Chinese Societies: A Comparative Study of Taiwan, Hong Kong and China' (2013) 28 International Sociology 277, 278.

${ }^{89}$ Ibid 277.
} 
one's parent's care and sacrifice'. ' ${ }^{90}$ 'Xiao' is particularly important in the context of agriculture, where growing old meant the loss of production capability, and elderly parents. Children would therefore voluntarily perform work to help support their family, explicitly and implicitly demonstrating their love and care for their parents. Authoritarian filial piety or 'jing' obliged children to be thankful to their parents for their care, signifying respect for and obedience to the elderly. ${ }^{91}$ This subsequently constituted the moral imperative to observe 'xiao' in a child's conduct and way of life.

These values help explain why children in less wealthier families voluntarily engage in labour to support their family financially. Is it the persistence of moralism in Chinese law $^{92}$ that strongly influences a child to have this ultimate virtue of filial piety as an essential way of living. As a consequence, these cultural values effectively deny children their childhood. In Western society, there is a tendency to attach more significance to the term 'childhood', 'a state where the child can experience freedom and pleasure, but is at the same time protected from the harsh reality of the outside world, preserving the

\footnotetext{
90 Ibid.

${ }^{91} \mathrm{Hu}$ and Scott, above n 72, 1270.

${ }^{92}$ Philip C. C. Huang, 'Morality and Law in China, Past and Present' (2015) 41 Modern China 3, 10.

child as innocent of adult worries'.93 However, through the lens of traditional China, the childhood experience may be different because of these cultural and religious values. As a result, a child's role and obligations in China will differ from that of another culture, because the term 'child' and 'childhood' varies depending on culture and society.

\section{Consequences of Child Labour}

Child labour effects not only the child, but also the Chinese economy, the global corporations that employ the labour of children and the wider community. What differs however is the extent of detriment that child labour can cause to each party.

\section{i. The Child}

The effects of child labour are felt greatest on the child being exploited. Longterm detriment is caused to the child's physical, mental and emotional wellbeing. Child labourers in agriculture and the industry sector suffer great physical injury as often they 'endure excessive and inappropriate hours of exhausting work that is performed under unhealthy and often dangerous conditions'. ${ }^{94}$ Particularly in agriculture, children frequently are exposed to pesticides and suffer from heat exhaustion and other illnesses related to insufficient or

\footnotetext{
93 Sharon Brookshaw, 'The Material Culture of Children and Childhood' (2009) 14 Journal of Material Culture 365, 366.

${ }^{94}$ Polakoff, above n 2, 267.
} 
contaminated water and lack of sanitation. ${ }^{95}$

What results is a child who is malnourished and has growth deficiencies. ${ }^{96}$

In a similar manner, child labour traumatically affects a child's mental and emotional wellbeing. They are likely to suffer from emotional abuse by their employers $^{97}$ and experience emotional difficulties caused by excessive pressure at work and high expectations at home. ${ }^{98}$ Furthermore, the demanding nature of the work itself has an immense impact on a child's social and educational development. ${ }^{99}$ It can interfere with their schooling, and can eventually lead to the child leaving their educational endeavours behind in favour of working to contribute to their family's survival despite extremely low wages. The result is that the child is unable to develop the necessary interactive and cognitive skills necessary for a healthy life. Children need to build personal positive relationships in order to have self confidence, and spending long hours at work deprives children from developing these relationships. As a result, child labourers

\footnotetext{
95 Ibid.

${ }^{96}$ Paola Roggero et al, The Health Impact of Child Labour in Developing Countries: Evidence from Cross-Country Data (2007) National Center for Biotechnology Information <https://www.ncbi.nlm.nih.gov/pmc/articles/PMC1 781398/>.

${ }_{97}$ Liao and Hong, above n 4, 567.

98 Orna Naftali, 'Recovering Childhood: Play, Pedagogy, and the Rise of Psychological Knowledge in Contemporary Urban China' (2010) 36 Modern China 589, 593.

${ }^{99}$ Polakoff, above n 2, 267.
}

can experience depression. Child labour can ultimately deprive the child's identity.

\section{ii. The Economy}

Child labour has economic value, in which it is low cost labour and makes it attractive for foreign investment and business expansion. ${ }^{100}$ It is low cost labour as particularly in the industry and service sectors, children that work are mostly unskilled. $^{101}$ This has the potential to otherwise reduce adult wages. As a result, children are substituted for adult labourers and increase their rate of labour force participation.

The existence of child labour therefore has a negative long-term effect on China's economic growth, labour market, foreign investments and broader measures of human development. Unsustainable economic growth in China perpetuates poverty, which allows child labour to exist. By interfering with the accumulation of human capital, child labour reduces the adulthood labour market productivity of child workers, which ultimately discourages growth and development economically. ${ }^{102}$ Without sustained economic growth, there are weak employment opportunities, and this acts as a disincentive for Chinese families to invest in

100 Elena Samonova, 'Socioeconomic Impacts of Child Labour' (Paper presented at The $2^{\text {nd }}$ Global Virtue Conference, Free University Berlin, 2014) 2.

101 Ibid.

102 Nardos Kebreab Tesfay, Child Labour and Economic Growth (Graduate Thesis, University of Saskatchewan, 2003) 2. 
their child's education. This slows down human development, which is required for economic prosperity. Furthermore, by reducing adult wages, child labour results in households becoming more reliant on children as income earning assets. ${ }^{103}$ This is particularly significant in less wealthier Chinese households. In China, there is already strong dependence on children for financial security and old-age support as children by cultural virtue are required to uphold filial piety. Ultimately, the economic entwined with the cultural perceptions towards the value of a child's productivity allows child labour to persist in China, having severe negative consequences for China's economic growth and human development.

\section{iii. The Employer}

The ramifications of employing child labourers are quite severe. Employers, including global corporations who operate in China "who use child labour, shall be fined by the labour protection authorities at the rate of 5000 yuan per month for each child labourer used'. ${ }^{104}$ Furthermore, if an employer fails to make amends after being ordered by labour protection authorities to do so, the employer will be fined 10,000 yuan per month for each child labourer as well as have their business license

\footnotetext{
103 Ibid.

104 Regulations Banning Child Labour (The People's Republic of China) National People's Congress, 2002, art 6 .

revoked. ${ }^{105}$ Alternatively, the 'persons directly in charge and other personnel who carry direct responsibility [of employing child labour] shall be given administrative punishment involving demotion or dismissal or disciplinary punishment'. ${ }^{106}$ Although China's domestic legislation provides for this penalty, there remains the challenge of extensive monitoring of enterprises and enforcing such legislation. Legal enforcement may be weakened in favour of attracting foreign capital and increasing exports. This is because cheap labour, satisfied by child labour, is an 'indispensable asset in enhancing China's international competitiveness' ${ }^{107}$

Not only do enterprises face legal consequences, they also face condemnation from the international community. Consumers are quick to withdraw their support from global corporations that employ child labour, negatively affecting their profitability. The corporation's brand and reputation ${ }^{108}$ is consequently damaged, and the effects are long-term.

\section{iv. The Wider Community}

The practice of child labour compromises the future of the child's family and their wider community. Low levels of

\footnotetext{
105 Ibid.

106 Ibid.

107 Joseph Yu-shek Cheng, King-lun Ngok and Yan Huang, 'Multinational Corporations, Global Civil Society and Chinese Labour: Workers' Solidarity in China in the Era of Globalisation' (2011) 33 Economic and Industrial Democracy 379, 380.

${ }^{108}$ Ibid 391.
} 
education and poverty ${ }^{109}$ reduce long-term employment prospects. This is because children sacrifice their education in order to work and provide support for their family, diminishing a child's future ability to acquire a higher quality job and the wages that accompany it. ${ }^{110}$ In this way, the cycle of poverty and labour is reconstructed in the future generations.

Furthermore, child labour is associated with the development of poor health, as children are exposed to dangerous work conditions and chemicals when working in agriculture or the industry sector. What can occur is 'premature illness and disability in the individual as well as the community, through... environmental contamination'. 111

The effects child labour has on the child, on the economy and on employers ultimately contributes to the social exclusion of children in society. There lacks a strong and harmonious Chinese community because 'child labour prevents [the transformation of] existing power relations and [reinforces] the marginalised status of [children]'. ${ }^{112}$

\section{CONCLUSION}

Children are unable to access justice effectively as their adult counterparts within

\footnotetext{
109 Anaclaudia G. Fassa, David L. Parker and Thomas J. Scanlon, Child Labour: A Public Health Perspective (Oxford University Press, 2010) 40.

${ }^{110}$ Ibid.

${ }^{111}$ Ibid 41.

112 Samonova, above n 86.
}

Mainland China's current legal framework. Their human rights continue to be violated as child labouring in agriculture, industry and the service sector persists in a society that does not legally and practically implement the international standards safeguarding children's rights. The research findings have demonstrated that this is the reality despite China's ratification of the $U N$ Convention on the Rights of the Child $1989,{ }^{113}$ the ILO Convention No 138 and the ILO Convention No 182. What allows child labour to persist is the fact that even though China has ratified these international treaties, it does not automatically become a part of domestic law. This can be seen by the lack of any provision in The Minors Protection Law, ${ }^{114}$ which outlaws the employment of child labourers in China. The effectiveness of China's current legal framework in prohibiting child labour is called into question, as well as their ability to meaningfully fulfill their international obligations. The causes of child labour cannot be limited to the ineffectiveness of China's legal framework alone. The findings on globalisation, economic growth, limited education and social and cultural constructions of 'child' and 'childhood' demonstrate that child labour persists as a

\footnotetext{
113 Convention on the Rights of the Child, opened for signature 20 November 1989, 1577 UNTS 3 (entered into force 2 September 1990).

114 Minors Protection Law (The People's Republic of China) National People's Congress, 1 June 2007.
} 
result of the tension in maintaining Chinese culture in China's legal system and the influence of international legal standards. Such consequences merit further exploration in future research.

\section{REFERENCES}

\section{Journal Articles}

Axford, Nick, 'Exploring the Influence of International Governmental Organisations on Domestic Child Welfare Policy and Practice' (2013) 37 Adoption \& Fostering 57

Brookshaw, Sharon, 'The Material Culture of Children and Childhood' (2009) 14 Journal of Material Culture 365

Ch, Muhammad Akram et al, 'Globalisation and its Impact on the World Economic Development' (2011) 2 International Journal of Business and Social Science 291

Cheng, Joseph Yu-shek, King-lun Ngok and Yan Huang, 'Multinational Corporations, Global Civil Society and Chinese Labour: Workers' Solidarity in China in the Era of Globalisation' (2011) 33 Economic and Industrial Democracy 379

Chung, Sunwook, 'Explaining Compliance:

A Multi-Actor Framework for Understanding Labour Law Compliance in China' (2014) 68 Human Relations 237
Dunford, Michael et al, 'Globalisation, Cost Competitiveness and International Trade: The Evolution of the Italian Textile and Clothing Industries and the Growth of Trade with China' (2016) 23 European Urban and Regional Studies 111

Grugel, Jean, 'Children's Rights and Children's Welfare After the Convention on the Rights of the Child' (2012) 13 Progress in Development Studies 19

$\mathrm{Hu}$, Yang and Jacqueline Scott, 'Family and Gender Values in China: Generational, Geographic and Gender Differences' (2014) 37 Journal of Family Issues 1267

Huang, Philip C. C., 'Morality and Law in China, Past and Present' (2015) 41 Modern China 3

Huang, Zhongjing, Ting Wang and Xiaojun Li, 'The Political Dynamics of Educational Changes in China' (2016) 14 Policy Futures in Education 24

Hurst, Peter, 'Health and Child Labour in Agriculture' (2007) 28 Food and Nutrition Bulletin 364

Ibhawoh, Bonny, 'Human Rights for Some: Universal Human Rights, Sexual Minorities and the Exclusionary Impulse' (2014) 69 International Journal 612 
Kahn-Nisser, Sara, 'External Governance, Convention Ratification and Monitoring: The EU, the ILO and Labour Standards in EU Accession Countries' (2014) 20 European Journal of Industrial Relations 383

Liao, Minli and Jun Sung Hong, 'Child Labour in the People's Republic of China: An Ecological Systems Analysis' (2010) 54 International Social Work 565

Liu, Fengshu, 'Negotiating the Filial Self' (2008) 16 Nordic Journal of Youth Research 409

Naftali, Orna, 'Recovering Childhood: Play, Pedagogy, and the Rise of Psychological Knowledge in Contemporary Urban China' (2010) 36 Modern China 589

Polakoff, Erica G, 'Globalisation and Child Labour' (2007) 23 Journal of Developing Societies 259

Sheng, Xuewen and Barbara H. Settles, 'Intergenerational Relationships and Elderly Care in China' (2006) 54 Current Sociology 293

Shi, Wuhong, 'The Application of Treaties in China: Practice, Problems and Prospects' (2012) 1 Journal of International Law 114

Thomas, Nigel, 'Children's Rights: Policy into Practice' (2011) 4 Centre for
Children and Young People:

Background Briefing Series 1

Xue, Hanqin and Qian Jin, 'International Treaties in the Chinese Domestic Legal System' (2009) 8 Chinese Journal of International Law 299

Yeh, Kuang-Hui et al, 'Filial Piety in Contemporary Chinese Societies: A Comparative Study of Taiwan, Hong Kong and China' (2013) 28 International Sociology 277

\section{Books}

Fassa, Anaclaudia G., David L. Parker and Thomas J. Scanlon, Child Labour: A Public Health Perspective (Oxford University Press, 2010)

\section{Legislation}

Compulsory Education Law (The People's Republic of China) National People's Congress, Order No 38, 12 April 1986 [Constitution of the People's Republic of China]

Minors Protection Law (The People's Republic of China) National People's Congress, 1 June 2007

Procedure of the Conclusion of Treaties (The People's Republic of China) National People's Congress, Order No 37, 28 December 1990 ('The Treaty Procedure Law')

Provisions on the Prohibition of Using Child Labour (The People's Republic 
of China) National People's Congress, Decree No. 364, 1 October 2002

Regulations Banning Child Labour (The People's Republic of China) National People's Congress, 2002

\section{Conventions}

Convention on the Rights of the Child, opened for signature 20 November 1989, 1577 UNTS 3 (entered into force 2 September 1990)

Minimum Age Convention, opened for signature 26 June 1973, C No 138 (entered into force 19 June 1976)

Universal Declaration of Human Rights, GA Res 217A (III), UN GAOR, $3^{\text {rd }}$ sess, $183^{\text {rd }}$ plen mtg, UN Doc A/810 (10 December 1948)

Worst Forms of Child Labour Convention, opened for signature 17 June 1999, C No 182 (entered into force 19 November 2000)

\section{Other}

International Labour Organisation, Child Labour in Agriculture $<$ http://ilo.org/ipec/areas/Agriculture/1 ang--en/index.htm>
International Labour Organisation, Child Labour in China and Mongolia <http://ilo.org/beijing/areas-ofwork/child-labour/lang--en/index.htm>

International Labour Organisation, What is Child Labour $<$ http://ilo.org/ipec/facts/lang-en/index.htm>

Roggero, Paola et al, The Health Impact of Child Labour in Developing Countries: Evidence from CrossCountry Data (2007) National Center for Biotechnology Information $<$ https://www.ncbi.nlm.nih.gov/pmc/ar $\underline{\text { ticles/PMC1781398/> }}$

Samonova, Elena, 'Socioeconomic Impacts of Child Labour' (Paper presented at The $2^{\text {nd }}$ Global Virtue Conference, Free University Berlin, 2014)

Tesfay, Nardos Kebreab, Child Labour and Economic Growth (Graduate Thesis, University of Saskatchewan, 2003)

UNICEF Global Databases, Child Labour: Current Status and Progress (2016) $<$ https://data.unicef.org/topic/childprotection/child-labour/\#> 